\title{
Apoptosis and Its Relation to the Cell Cycle in the Developing Cerebral Cortex
}

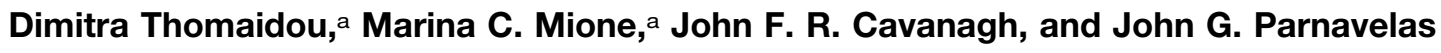 \\ Department of Anatomy and Developmental Biology, University College London, London WC1E 6BT, United Kingdom
}

Large numbers of dying cells are found in proliferating tissues, suggesting a link between cell death and cell division. We detected and quantified dying cells during pre- and early postnatal development of the rat cerebral cortex using in situ end labeling of DNA fragmentation [terminal deoxynucleotidyl transferase-mediated dUTP-biotin nick end labeling (TUNEL)] and electron microscopy. The proliferative zones that give rise to the neuronal and glial cell types of the cortex, the ventricular and, to a larger extent, the subventricular zones showed higher incidence of cell death than other regions of the developing cortex during the period of neurogenesis. Gel electrophoresis of DNA isolated from the subventricular zone of newborn animals showed a ladder pattern that is characteristic of apoptosis. The number of apoptotic cells remained high in this zone for at least 2 weeks, during which period cells continued to divide. The correlation between cell division and cell death was studied in the subventricular zone of newborn rats; cumulative labeling with bromodeoxyuridine showed that $71 \%$ of TUNEL-labeled cells had taken up this S-phase marker before undergoing cell death. Using bromodeoxyuridine and $\left[{ }^{3} \mathrm{H}\right]$-thymidine in succession to identify a cohort of proliferating cells, we found that the clearance time of TUNEL-positive nuclei was $2 \mathrm{hr}$ and $20 \mathrm{~min}$. A comparison between the number of mitotic figures and that of TUNEL-positive nuclei showed that cell death affects one in every 14 cells produced by dividing ventricular zone cells at embryonic day 16 and one in every 1.5 cells produced in the subventricular zone of newborn rats. In addition, we found that most of TUNEL-positive cells were in the G1 phase of their cell cycle. We conclude that apoptosis is prominent in the proliferating neuroepithelium of the developing rat cerebral cortex and that it is related to the progression of the cell cycle.

Key words: neocortex; development; cell death; proliferation; BrdU; rat
During the development of multicellular organisms, cells are actively involved in two opposing processes: proliferation and death (Glücksmann, 1951; Saunders, 1966). Both processes are controlled genetically, and cell death in development has been renamed "naturally occurring programmed cell death" (Oppenheim, 1991) to emphasize the activation of an endogenous program of self-destruction. This type of cell death often has the morphological appearance of apoptosis (Wyllie et al., 1980), characterized by nuclear condensation, and nuclear and cellular blebbing (Clarke, 1990). The simultaneous occurrence of both proliferation and apoptosis in some cell populations has suggested that the two processes may be related. Indeed, besides morphological similarities between dying and dividing cells, recent studies have shown that molecules acting during cell cycle progression are required for apoptosis. These include mitotic kinases (Meikrantz et al., 1994), the tumor suppressor gene p53 (Kuerbitz et al., 1992), and cyclin $D_{1}$ (Freeman et al., 1994). Similarly, molecules that act as checkpoints during the progression through the cell cycle have been shown to prevent apoptosis. One of these molecules, p105 ${ }^{\mathrm{rb}}$ (product of the retinoblastoma gene), blocks cell cycle progression at the late G1 restriction point (Pardee, 1989).

Apoptosis has been recognized as a prominent event during the

Received Sept. 23, 1996; revised Nov. 8, 1996; accepted Nov. 13, 1996.

This work was supported by the Wellcome Trust. We thank Bagi Nadarajah for her help with the confocal microscope and Peter Boardman and Brett Harris for technical assistance.

Correspondence should be addressed to Dr. John G. Parnavelas, Department of Anatomy and Developmental Biology, University College London, Gower Street, London WC1E 6BT, UK.

${ }^{\text {a }}$ These authors contributed equally to this work

Copyright (C) 1997 Society for Neuroscience $0270-6474 / 97 / 171075-11 \$ 05.00 / 0$ development of the vertebrate nervous system. During embryogenesis, cell death has a morphogenetic function at various stages of the formation of the CNS: during the closure of the neural tube (Geelen and Langman, 1977), during the development of the mesencephalic region (Graham et al., 1993), and in the process of negative selection of certain progenitor cells from inappropriate regions (Homma et al., 1994). Later in development, neurons generated in some areas of the nervous system may die as a result of limited availability of trophic factors or lack of synaptic inputs necessary to suppress the endogenous genetic death program (Oppenheim, 1991; Barres et al., 1992; Raff et al., 1993). Based on the time of occurrence of cell death, it is possible to hypothesize the existence of two functionally distinct types of death in the nervous system of developing mammals. They may share morphological (apoptosis) and/or biochemical (activation of cell cycle genes) similarities but differ substantially in the cell types involved: the "proliferative" cell death involves actively cycling cells, whereas "target-related" cell death involves postmitotic neurons.

The occurrence of "proliferative" cell death in the cerebral cortex of embryos often has been regarded as a rare event, based on the paucity of morphological correlates of apoptosis in the ventricular zone (VZ) and subventricular zone (SVZ). In all recent studies using conventional staining techniques, electron microscopy or in situ end labeling of DNA fragmentation [terminal deoxynucleotidyl transferase-mediated dUTP-biotin nick end labeling (TUNEL)], cell death in the VZ and SVZ of rat and mouse embryos of different ages has been reported as rare or absent (Ferrer et al., 1992; Reznikov and van der Kooy, 1995; Spreafico et al., 1995). An exception to this is a recent study by Blaschke et al. (1996) who reported, with the use of a highly 
sensitive technique (in situ end labeling, ISEL) for detecting dying cells, that up to $70 \%$ of the cells within the proliferative neuroepithelium die. The difference between the numbers reported by these authors and those found in earlier studies could be explained by (1) the sensitivity of the ISEL technique and (2) the long clearance time of ISEL-positive cells (Voyvodic, 1996). Moreover, examples of "proliferative" cell death in the CNS have been found in various mutants. In transgenic mice, in which the $r b$ gene has been knocked out, apoptotic cells accumulate at the VZ/SVZ border of E16 embryos (Lee et al., 1992). In lurcher (Wetts and Herrup, 1982) and staggerer mutants (Herrup, 1983), the death of cerebellar granule cells is accompanied by the activation of genes involved in mitosis (Herrup and Busser, 1995). These reports suggest that CNS progenitor cells may undergo "proliferative" apoptosis, similar to other proliferating tissues (Wyllie et al., 1980), but either this event is not numerically significant or it takes place so quickly that only a few apoptotic nuclei may be detected in a histological section at any one time. In support of the latter possibility is evidence showing that the histologically visible stages of the apoptotic process are very short, lasting from a few minutes to a maximum of $3 \mathrm{hr}$ (for review, see Bursch et al., 1990).

In the present study, we evaluated the relationship between cell death and cell cycle progression in the VZ of embryonic day (E) 14, E16, and E19 rats and in the SVZ of newborn rats. Because the total amount of "proliferative" cell death in these regions was not known, we first determined the proportion of dying cells within the proliferating population by comparing the number of mitoses to apoptotic cells after the evaluation of the length of the two processes. A labeling protocol, originally applied to mark a cohort of dividing cells (Takahashi et al., 1992), was used to investigate the length of the dying process and whether this takes place during a specific phase of the cell cycle. Our results indicate that apoptosis is widespread among proliferating cells of the VZ and SVZ and that this event takes place during G1 phase.

\section{MATERIALS AND METHODS}

Tissue preparation. For the identification of dying cells, we used two E14, three E16 and E19, six newborn, two 1-week-old, and two 2-week-old Sprague Dawley rats. The day in which a vaginal plug was found in pregnant rats was considered as E1. Rats were fixed with $4 \%$ paraformaldehyde in $0.1 \mathrm{M}$ phosphate buffer, $\mathrm{pH} 7.4$ (PB), either by immersion (E14 and E16) or by transcardiac perfusion (E19 and postnatal rats). Dying cells were visualized via TUNEL in paraffin wax sections and toluidine blue in Araldite-embedded sections. For the visualization of TUNEL-positive cells, brains were removed, placed in the same fixative for $2 \mathrm{hr}$, and then transferred into PB. Then they were dehydrated through an ascending series of ethanol, followed by chloroform, and embedded in paraffin wax. Serial sections, $10 \mu \mathrm{m}$ thick, were cut in the coronal plane from each brain, deparaffinized with xylene, and rehydrated through a descending series of ethanol.

For electron microscopy and for counting mitotic figures and pyknotic nuclei of telencephalic proliferative zones, animals were fixed with $4 \%$ paraformaldehyde and $0.2 \%$ glutaraldehyde in PB. Approximately 1-mmthick coronal slices were cut through E19 and postnatal brains with a razor blade, whereas E14 and E16 brains were left whole and processed for electron microscopy as described previously (Parnavelas et al., 1983). Briefly, the slices or the early embryonic brains were post-fixed in $2 \%$ $\mathrm{OsO}_{4}$ for $2 \mathrm{hr}$, rinsed in buffer, stained in aqueous $1 \%$ uranyl acetate for $1.5 \mathrm{hr}$, dehydrated in ethanol, and embedded in Araldite. Ultrathin sections were cut with an ultramicrotome, counterstained with aqueous uranyl acetate and lead citrate, and examined with a Zeiss EM 910 electron microscope. Mitotic figures and pyknotic nuclei were counted in $1-\mu \mathrm{m}$-thick semithin sections stained with $1 \%$ toluidine blue and $0.5 \%$ safranin (Martín-Partido et al., 1986) using an ocular grid and a $63 \times$ objective lens.

Apoptotic cells detected with TUNEL. The method used was a modifi- cation of the technique described by Gavrieli et al. (1992). Every fifth section in a series of $10-\mu \mathrm{m}$-thick paraffin sections was preincubated for $5 \mathrm{~min}$ in $30 \mathrm{mM}$ Tris buffer containing $2.5 \mathrm{mM} \mathrm{CaCl}_{2}$ (proteinase $\mathrm{K}$ buffer), followed by a $15 \mathrm{~min}$ incubation in $10 \mu \mathrm{g} / \mathrm{ml}$ proteinase $\mathrm{K}$. The sections were washed twice with distilled (d) $\mathrm{H}_{2} \mathrm{O}$ and preincubated for $15 \mathrm{~min}$ in terminal transferase (TdT) buffer (30 mM Tris buffer, pH 7.2, $140 \mathrm{~mm}$ sodium cacodylate, and $1 \mathrm{~mm}$ cobalt chloride), followed by incubation in $1 \mathrm{U} / 100 \mu \mathrm{l}$ TdT and $1 \mathrm{U} / 100 \mu \mathrm{l}$ biotinylated-d-UTP (bio-11-dUTP) at $37^{\circ} \mathrm{C}$ for $60 \mathrm{~min}$. The reaction was terminated by rinsing the slides in $\mathrm{dH}_{2} \mathrm{O}$, followed by $0.1 \mathrm{~m}$ PBS for $5 \mathrm{~min}$. Nonspecific binding sites were blocked with $10 \%$ normal goat serum for $30 \mathrm{~min}$. Then the sections were incubated for $2 \mathrm{hr}$ with streptavidin conjugated with peroxidase (ABC complex; Vector Laboratories, Burlingame, CA) diluted 1:1000 in PBS. The reaction product was visualized with $0.05 \%$ diaminobenzidine (DAB) and $0.005 \% \mathrm{H}_{2} \mathrm{O}_{2}$ for $15 \mathrm{~min}$. Sections were counterstained very lightly with hematoxylin, dehydrated through an ascending series of ethanol and xylene, and mounted with DPX.

To evaluate the percentage of TUNEL-positive cells in different regions of the developing cortex, camera lucida drawings of the stained sections were made at a final magnification of $400 \times$, and the positions of TUNEL-positive nuclei were noted. The total area occupied by both labeled and unlabeled cells in every region examined was estimated from the drawings, using the TABLYT software developed by Dr. J. Cook (UCL, London, UK). The size of the nuclear profiles of unlabeled and TUNEL-positive cells was estimated by measuring the area of each nuclear profile in a total of 100 cells from each age group at a magnification of $550 \times$. The nuclei of TUNEL-positive cells were found to be somewhat smaller than those of unlabeled cells, but the difference was not significant; for this reason, no correction factor was introduced in our counts. Knowing the area occupied by each nuclear profile, their density, and the total area of each region examined, we calculated the total number of cells and the ratio of TUNEL-positive cells per total cell population in all zones of the developing cortex at each age examined.

Cell cycle kinetics in the SVZ of newborn rats. To evaluate the relationship between cell death and cell cycle in the proliferative zones of the developing rat cortex, we sought to compare the kinetics of the two events. Although cell cycle parameters of the VZ of rat embryos have been reported in several studies (Waechter and Jaensch, 1972; Schultze et al., 1974; Reznikov and van der Kooy, 1995), no information is available for the SVZ of newborn rats, an area in which we found a large number of TUNEL-positive cells.

The lengths of the cell cycle $\left(T_{\mathrm{C}}\right)$ and $\mathrm{G} 2+\mathrm{M}\left(T_{\mathrm{G} 2+\mathrm{M}}\right)$ were evaluated via the labeled mitoses method (Baserga, 1985) with a single pulse of BrdU as a marker of S phase. Briefly, BrdU $(50 \mathrm{mg} / \mathrm{kg}$, diluted in sterile saline containing $0.007 \mathrm{~N} \mathrm{NaOH}$ ) was injected intraperitoneally into 14 newborn rats at 8 A.M. Two animals were perfused with $4 \%$ paraformaldehyde $/ 0.5 \%$ glutaraldehyde in $\mathrm{PB}$ at each of the following time points after the injection of BrdU: 2, 3, 4, 14.5, 16, 18, and $20 \mathrm{hr}$. For each time point, two half-brains were embedded in Araldite as described above, while the other halves were embedded in paraffin wax. We used both Araldite and paraffin wax sections to ensure that all mitotic figures could be detected. We obtained comparable results, but mitoses (both labeled and unlabeled) were easier to detect in Araldite sections. Series of 10 consecutive semithin sections ( $1 \mu \mathrm{m}$ thick), encompassing the SVZ, were mounted on poly-L-lysine-coated slides. Each series was separated from the next by at least $50 \mu \mathrm{m}$. Only the first and fifth sections of each sequence were processed for BrdU immunohistochemistry using a postembedding protocol (Mione et al., 1994), and a monoclonal BrdU antibody (Sigma, St. Louis, MO) at a dilution of 1:500. Bromodeoxyuridine immunoreactivity was visualized with DAB as substrate. The sections adjacent to those processed for BrdU were stained with toluidine blue to identify mitotic figures, which then were evaluated for BrdU labeling. At least 16 sections from each brain were processed for BrdU immunohistochemistry, and a minimum of 200 subventricular mitoses per brain were evaluated. The paraffin-embedded hemispheres were cut at 5 $\mu \mathrm{m}$, and sections were treated with $2 \mathrm{~N} \mathrm{HCl}$ for $1 \mathrm{hr}$ and neutralized with $0.1 \mathrm{M}$ borate buffer before processing for BrdU immunohistochemistry. Sections were lightly counterstained with $1 \%$ toluidine blue.

The labeled mitoses method gives an accurate measurement of the length of S phase only when a short pulse of the label is given. Because it is known that thymidine analogs injected in vivo may be available to dividing cells for up to $2 \mathrm{hr}$ (Takahashi et al., 1992), the length of S phase for cycling SVZ cells was, therefore, evaluated using cumulative BrdU labeling as described in the following section. The labeling index (LI) in 
the SVZ, evaluated in both semithin and wax-embedded sections, was the number of cells labeled with BrdU $2 \mathrm{hr}$ after a single injection.

Cumulative labeling. This protocol was used to determine the length of $T_{\mathrm{S}}$ and confirm the length of $T_{\mathrm{C}}$ found with the labeled mitoses method. In addition, to evaluate whether all deaths in the SVZ were of proliferating cells, we performed TUNEL histochemistry in animals exposed to BrdU for $15 \mathrm{hr}$. BrdU (50 mg/kg, i.p.) was injected into newborn rats every $3 \mathrm{hr}$ for a total of $15 \mathrm{hr}$ (Nowakowski et al., 1989). Two rats were perfused with $4 \%$ paraformaldehyde $0.5 \mathrm{hr}$ after each injection of BrdU performed at 9 A.M., 12 noon, 3 P.M., 6 P.M., 9 P.M., and midnight. Brains were prepared as described for the labeled mitoses method. The two half-brains of newborn rats, which had received injections of BrdU over a period of $15 \mathrm{hr}$ as described above, were sectioned and processed for TUNEL histochemistry before BrdU immunohistochemistry. TUNEL reaction product was visualized with Texas Red-conjugated streptavidin (1:500). BrdU immunohistochemistry was performed as described above, with the exception that immunoreactivity was revealed with an FITCconjugated monoclonal antibody (Sigma).

Evaluation of the length of the apoptotic process and of the length of $M$ phase. The lengths of these two events were evaluated using a protocol initially described by Takahashi et al. (1992) to label a cohort of dividing cells that proceeds in synchrony through the cell cycle. The study was performed in the SVZ of newborn rats, in which we found the largest number of TUNEL-positive cells. In addition, we previously had evaluated the kinetics of the other cell cycle phases for these cells, the growth fraction, and the percentage of dying SVZ cells while proliferating. In brief, SVZ cells in S phase were labeled with a pulse of BrdU $(50 \mathrm{mg} / \mathrm{kg})$ injected intraperitoneally into newborn rats at 9 A.M. Forty minutes later, the rats received an injection of $\left[{ }^{3} \mathrm{H}\right]$-thymidine $(3 \mu \mathrm{Ci} / \mathrm{gm}$, specific activity 60-80 Ci/mM; Amersham, Arlington Heights, IL). This protocol created a cohort of cells that had exited $\mathrm{S}$ phase before $\left[{ }^{3} \mathrm{H}\right]$-thymidine was available, thus containing BrdU only, whereas all other cells in $\mathrm{S}$ phase were characterized by $\left[{ }^{3} \mathrm{H}\right]$-thymidine labeling either alone or in conjunction with BrdU. Animals were perfused with $4 \%$ paraformaldehyde in $\mathrm{PB}$ at $1 \mathrm{hr}$ intervals starting $1 \mathrm{hr}$ and $20 \mathrm{~min}$ after the initial injection of BrdU. The brains of these animals were removed and embedded in Araldite. Other animals injected as above were perfused at $2,3,4,5,6,7,8,10$, and $12 \mathrm{hr}$ after the BrdU injection and embedded in paraffin. Paraffin-embedded hemispheres were used for the evaluation of the length of the apoptotic process as follows: at least 10 sections $(10 \mu \mathrm{m}$ thick) per brain, each section separated from the following one by $50 \mu \mathrm{m}$, were processed for TUNEL histochemistry, using biotin-16-dUTP and streptavidin Texas Red as the secondary antibody. Bromodeoxyuridine immunohistochemistry was performed as described above and revealed using an FITC-conjugated second layer. After this reaction, sections were dried and dipped in photographic emulsion (G5, Ilford), exposed for $\sim 4$ weeks in the dark in $4{ }^{\circ} \mathrm{C}$, and developed with Kodak D-19 developer. To minimize variability among experiments, we processed and developed all slides together.

After autoradiography, all TUNEL-positive SVZ cells were evaluated for the localization of BrdU immunoreactivity and the presence of silver grains. Cells could be classified easily as $\left[{ }^{3} \mathrm{H}\right]$-thymidine-labeled or unlabeled because of the high number of silver grains found on labeled cells, as compared with background (15-20 grains/labeled cell after subtracting background grains). For each time point, we evaluated the percentages of TUNEL-positive cells labeled with BrdU only over the total number of TUNEL-positive cells. At least 100 TUNEL-positive cells were evaluated from each hemisphere.

Semithin sections of Araldite-embedded tissue were used for the evaluation of the length of the $\mathrm{M}$ phase. Briefly, series of 10 consecutive sections were mounted on different slides. The first and fifth sections of each series were processed for BrdU immunoreactivity, whereas the second and sixth sections were processed for autoradiography, as described above, followed by counterstaining with $1 \%$ toluidine blue. The same mitoses were clearly visible in at least seven consecutive semithin sections. Each mitosis was, therefore, scored as unlabeled, $\left[{ }^{3} \mathrm{H}\right]-$ thymidine-labeled, $\left[{ }^{3} \mathrm{H}\right]$-thymidine plus BrdU-labeled, or labeled only with BrdU. The length of $\mathrm{M}$ phase was calculated as described in Results.

DNA extraction and agarose gel electrophoresis. We used gel electrophoresis to confirm that DNA fragmentation caused by apoptosis was detectable in the SVZ of newborn rats. The SVZ and pieces of cerebral cortex were dissected out from fresh brains of newborn and adult rats, respectively, and immediately frozen in liquid nitrogen. The tissue was homogenized in liquid nitrogen and resuspended in extraction buffer (10 $\mathrm{mm}$ Tris- $\mathrm{HCl}, \mathrm{pH} 8,10 \mathrm{~mm}$ EDTA, and 0.5\% SDS) containing $50 \mu \mathrm{g} / \mathrm{ml}$
RNase I. After incubation for $1 \mathrm{hr}$ at $37^{\circ} \mathrm{C}, 100 \mu \mathrm{g} / \mathrm{ml}$ proteinase $\mathrm{K}$ was added, and the samples were left at $50^{\circ} \mathrm{C}$ for $3 \mathrm{hr}$. The DNA was extracted with phenol/chloroform (chloroform/isoamyl alcohol, 24:1) and precipitated overnight in absolute alcohol containing $0.3 \mathrm{~m}$ sodium acetate at $-20^{\circ} \mathrm{C}$. After centrifugation, the pellet was washed in $70 \%$ ethanol and resuspended in TE buffer ( $0.1 \mathrm{M}$ Tris- $\mathrm{HCl}, \mathrm{pH} 8.0$, and $10 \mathrm{mM}$ EDTA). Dexamethasone-treated thymocytes were used as positive controls for DNA fragmentation. Cultures of thymocytes were prepared as described by Gavrieli et al. (1992). DNA samples, $\sim 2.5 \mu \mathrm{g}$ each, were separated electrophoretically on $1 \%$ agarose gels containing ethidium bromide $(0.4$ $\mu \mathrm{g} / \mathrm{ml})$, viewed with UV transillumination $(302 \mathrm{~nm})$, and photographed with a Polaroid camera.

\section{RESULTS}

\section{Apoptotic cells in the developing neocortex}

Cells with the morphological features of apoptosis could be recognized easily in semithin sections stained with toluidine blue/ safranin (Fig. $1 A$ ), in paraffin sections stained with TUNEL immunohistochemistry (Fig. $1 B, C$ ), and in ultrathin sections (Fig. $1 D)$. These cells, scattered among numerous "healthy" cells, were present throughout the developing cortex at all ages examined. In semithin sections they were characterized by intense blue staining of the condensed nucleus or nuclear fragments and a shrunken cytoplasm (Fig. 1 $A$ ). In paraffin sections apoptotic cells, identified by intense labeling of their nucleus with streptavidin conjugated to biotinylated d-UTP, were visible both with the use of fluorescent (streptavidin Texas Red, Fig. $1 B$ ) or peroxidase (Fig. $1 C$ ) second layers. Examination with the electron microscope showed dying cells with characteristic dark condensed nuclei and cell membranes that often were detached from the surrounding neuropil (Fig. 1D).

The number of apoptotic cells found in semithin sections of embryonic and newborn rat brains was comparable to that of TUNEL-positive cells observed in paraffin sections, suggesting that the two methods allow visualization of the same population of dying cells (Table 1). The highest frequency of apoptotic cells, estimated to be $\sim 3 \%$ of the total number of cells present at a given time point, was observed in the SVZ of newborn rats, whereas in the embryonic VZ only one apoptotic cell was found for approximately every 200 cells at E14, one in every 110 cells at E16 and one in every 330 cells at E19 (Table 1). In early postnatal life, only a few TUNEL-positive cells were found in the cortical layers, with the vast majority distributed throughout the SVZ. Later in development, dying cells were restricted to the subependymal layer (Table 1; Fig. 2).

\section{TUNEL-positive SVZ cells are part of the proliferating population}

In newborn rats, the percentage of SVZ cells pulse-labeled with BrdU 2 hr earlier (LI) was $17.2 \pm 0.3 \%$. After cumulative BrdU labeling for $15.5 \mathrm{hr}$, as many as $57 \%$ of SVZ cells were labeled with BrdU (Fig. 3A), indicating that not all SVZ cells were proliferating. Indeed, a few late-born cortical neurons on their way to the cortex may still be at the level of the SVZ at birth (Ignacio et al., 1995); moreover, the SVZ is characterized by heterogeneous cell populations, and some cells may be postmitotic. To evaluate whether all dying cells in the SVZ were proliferating, we performed TUNEL histochemistry after cumulative BrdU labeling and found that $71 \pm 0.8 \%$ of TUNEL-positive cells also were labeled with BrdU (Fig. $7 A$ ), indicating that the majority of apoptotic cells take up this S-phase marker before dying. An interpretation of this finding is that the preponderance of dying cells belongs to the proliferative fraction rather than to the postmitotic population in the SVZ. 

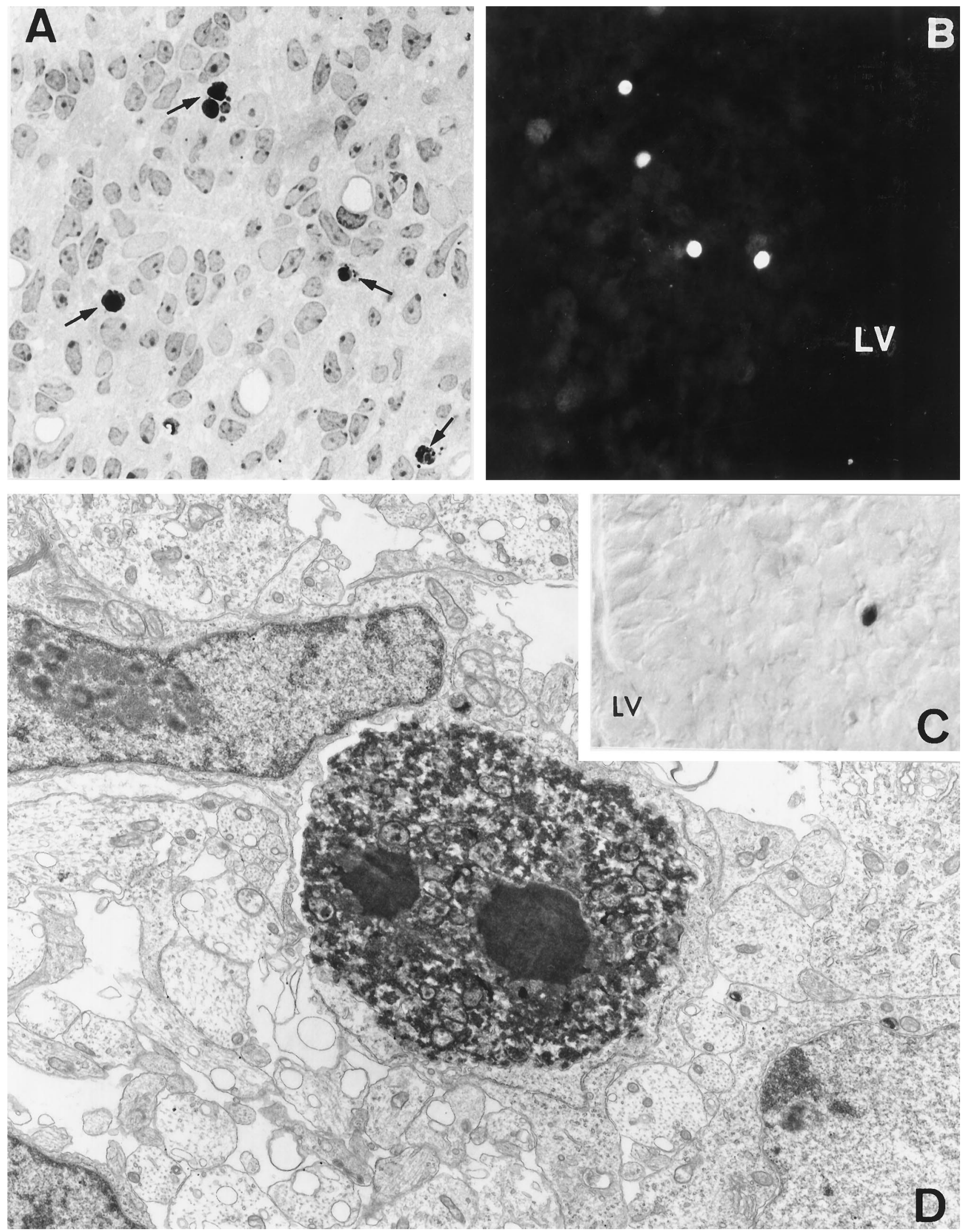

Figure 1. Apoptotic cells in the proliferative zones of the developing cortex. A, These cells (arrows) are distinguished by intense blue staining of the condensed nucleus in toluidine blue-stained semithin sections through the SVZ of an E19 rat. $B$, TUNEL-positive cells in the SVZ of a newborn rat revealed immunohistochemically using streptavidin Texas Red as a second layer. $C$, A TUNEL-positive cell in the SVZ of a newborn rat, using streptavidin peroxidase as a secondary antibody. $L V$, Lateral ventricle. $D$, Ultrathin section through the VZ of an E16 rat showing a cell with typical morphological characteristics of apoptosis. Magnifications: $A-C, 640 \times ; D, 11,700 \times$. 


\begin{tabular}{|c|c|c|c|c|c|c|}
\hline & & $\mathrm{VZ}$ & SVZ & IZ & SP & $\mathrm{CP}$ \\
\hline \multirow[t]{2}{*}{ E14 } & TUNEL & $5 \pm 0.3$ & - & - & - & - \\
\hline & Pyknotic & $3.3 \pm 0.51$ & - & - & - & - \\
\hline \multirow[t]{2}{*}{ E16 } & TUNEL & $9 \pm 0.6$ & - & $4 \pm 0.3$ & - & - \\
\hline & Pyknotic & $10.3 \pm 1.86$ & - & $7.4 \pm 1.75$ & - & - \\
\hline \multirow[t]{2}{*}{ E19 } & TUNEL & $3 \pm 0.9$ & $15 \pm 1$ & $1 \pm 0.2$ & $0.5 \pm 0.1$ & $0.5 \pm 0.1$ \\
\hline & Pyknotic & $4.4 \pm 1.19$ & $16.5 \pm 2.26$ & $2.6 \pm 1.18$ & $1.3 \pm 0.59$ & 0 \\
\hline \multirow[t]{2}{*}{ P0 } & TUNEL & $3 \pm 0.5$ & $30 \pm 1.5$ & - & - & $4 \pm 0.2$ \\
\hline & Pyknotic & $3.1 \pm 0.77$ & $35.9 \pm 1.33$ & - & - & $4.7 \pm 0.93$ \\
\hline \multirow[t]{2}{*}{ P7 } & TUNEL & $2 \pm 0.2$ & $31 \pm 2.3$ & - & - & $3 \pm 0.3$ \\
\hline & Pyknotic & $1.2 \pm 0.49$ & $33 \pm 4.3$ & - & - & - \\
\hline \multirow[t]{2}{*}{ P14 } & TUNEL & $2 \pm 0.5$ & $33 \pm 2$ & - & - & $1 \pm 0.1$ \\
\hline & Pyknotic & $2 \pm 0.71$ & $13.4 \pm 2.6$ & - & - & - \\
\hline
\end{tabular}

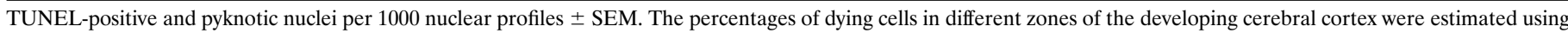
both the TUNEL method to detect apoptotic nuclei in paraffin sections and semithin sections to detect pyknotic nuclei.

\section{Cell cycle parameters in the SVZ}

Plots of the percentages of labeled mitoses in the SVZ of newborn rats after a single pulse of BrdU (Fig. $4 A$ ) allowed us to determine the length of the cell cycle $\left(T_{\mathrm{C}}\right)$ and the length of $\mathrm{G} 2+\mathrm{M}$ $\left(T_{\mathrm{G} 2+\mathrm{M}}\right) . T_{\mathrm{C}}$ was measured between the $50 \%$ labeling points of the two ascending curves and corresponded to $17 \mathrm{hr}$, whereas $T_{\mathrm{G} 2+\mathrm{M}}$ was determined directly as the interval between the injection and the $50 \%$ labeling point of the first ascending curve, corresponding to $3 \mathrm{hr}$ (Fig. $4 A$ ).

Cumulative labeling with BrdU (Fig. $4 B$ ) gave similar results for $T_{\mathrm{C}}$. This approach was used primarily to evaluate the length of $T_{\mathrm{S}}$. In the curve of cumulative labeling, the time point at which the LI reaches a plateau $(13.5 \mathrm{hr})$ corresponds to $T_{\mathrm{C}}-T_{\mathrm{S}}$. In addition, the intercept of the curve with the $y$-axis represents $T_{\mathrm{S}} / T_{\mathrm{C}} \times \mathrm{LI}$. From the cumulative labeling curve, $T_{\mathrm{S}}$ appeared to be $5.1 \mathrm{hr}$, and $T_{\mathrm{C}}$ was $18.6 \mathrm{hr}$. $T_{\mathrm{G} 1}$ was evaluated as $T_{\mathrm{C}}-\left(T_{\mathrm{S}}+\right.$ $\left.T_{\mathrm{G} 2+\mathrm{M}}\right)$ and was estimated to be $10.75 \mathrm{hr}$. The growth fraction (GF), i.e., the fraction of proliferating SVZ cells, was 57\%. To determine $T_{\mathrm{M}}$ accurately, we followed a cohort of proliferating cells that passed synchronously through different phases of the cell cycle (see Fig. 5) and were labeled only with BrdU. The size of this cohort corresponded to the labeling time (Fig. 5A,B). The length of $\mathrm{M}$ phase could be evaluated by subtracting the labeling time (the interval between the two injections) from the length of time

Table 2. Dying cells in the proliferative zones (VZ and SVZ) of the rat cerebral cortex

\begin{tabular}{llllll} 
Age & $\begin{array}{l}\text { Pyknotic } \\
(\%)\end{array}$ & $\begin{array}{l}\text { Mitotic } \\
(\%)\end{array}$ & GF & $\begin{array}{l}\text { Dying cells } \\
(\%)\end{array}$ & $\begin{array}{l}\text { Newly generated } \\
\text { cells that die }\end{array}$ \\
\hline E14 & 0.3 & 6.2 & $100^{a}$ & 1.72 & $1: 58$ \\
E16 & 1.3 & 5.12 & $100^{a}$ & 8.8 & $1: 11.3$ \\
E19 & 1.6 & 3.3 & $100^{a}$ & 17.5 & $1: 5.7$ \\
P0 & 3.5 & 1.9 & $57^{b}$ & 36.75 & $1: 2.7$
\end{tabular}

Evaluation of total numbers of cells dying in the proliferative zones of the developing cortex, comparing the lengths of the apoptotic and mitotic processes. Based on our results, the ratio between mitosis and apoptosis is 1:2.8 $=0.35$. Knowing the percentages of dying and dividing cells and the growth fraction (GF) at each age examined, we evaluated the numbers of dying cells by using the following formula: $\%$ dying cells $=\left(\frac{\% \text { pyknoses } \times \mathrm{GF}}{\% \text { mitoses }}\right) \times 0.35$.

${ }^{a}$ Waechter and Jaensch, 1972.

${ }^{b}$ Present work. during which mitoses labeled with BrdU only were visualized and corresponded to not more than 50 min (Fig. 6).

\section{Length of the histologically visible phases of apoptosis using TUNEL}

We followed the cohort of proliferating SVZ cells labeled with BrdU for several hours to investigate the kinetics of cell death in proliferating cells. The first TUNEL-positive cells double-labeled with BrdU, but not with $\left[{ }^{3} \mathrm{H}\right]$-thymidine, appeared $5 \mathrm{hr}$ after the injection of the first marker (Fig. $7 B$ ). These cells reached a maximum of $56 \pm 0.5 \%$ of all TUNEL-positive cells at 6-7 hr after the initial injection. They were detectable up to $8 \mathrm{hr}$ after BrdU injection (18 $\pm 0.6 \%$ of TUNEL-positive cells), i.e., for a total of $3 \mathrm{hr}$. All TUNEL-labeled cells detected after this time were labeled with both $\mathrm{BrdU}$ and $\left[{ }^{3} \mathrm{H}\right]$-thymidine or $\left[{ }^{3} \mathrm{H}\right]$ thymidine alone (Fig. $7 B$ ). After subtraction of the labeling time, this gave an estimate of $2 \mathrm{hr}$ and $20 \mathrm{~min}$ as the duration of the apoptotic process. The fact that dying cells belonging to this identifiable cohort were found only between 5 and $8 \mathrm{hr}$ after the initial injection indicated that (1) the clearance time of TUNELpositive cells in the SVZ of newborn rats is on average $2-3 \mathrm{hr}$, and (2) cells visualized with TUNEL are in G1.

\section{Comparison between the length of mitosis and that of apoptosis}

Because of the similarly brief duration of mitosis and apoptosis, cells engaged in one of these two events represent only a small fraction of the cells in proliferating tissues. For example, the proportion of proliferating cells in the VZ of E14 rat embryos is $100 \%$, yet the percentage of mitoses visible at any time point is only $6 \%$ (Reznikov and van der Kooy, 1995). Based on our results (Table 2), the ratio between the duration of mitosis and apoptosis is 1:2.8. Assuming that the length of the two processes remains constant during development, we have calculated the percentage of cells dying in VZ and SVZ from the number of mitoses and apoptoses that were visualized. The results of this calculation are shown in Table 2.

\section{DNA laddering}

The large number of dying cells found in the proliferative zones of the developing rat brain, and in particular in the SVZ of newborn rats, suggested that DNA fragmentation caused by apoptosis may be detected with electrophoresis. This method has been reported 

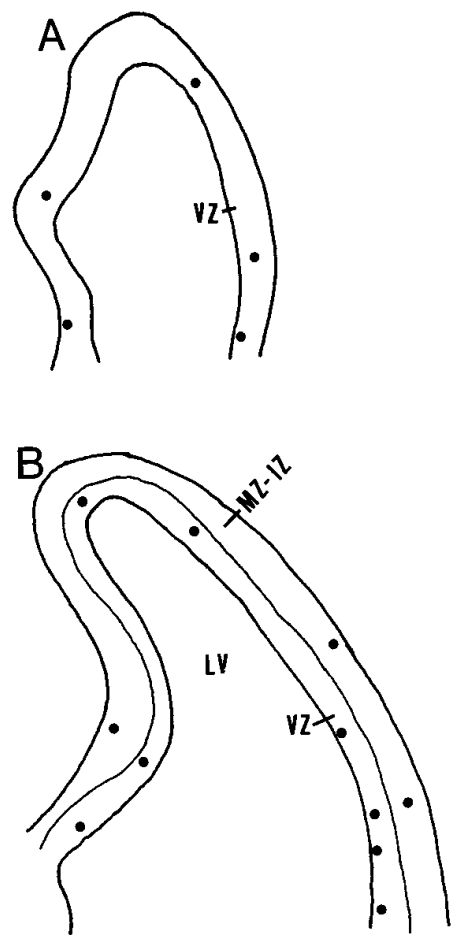
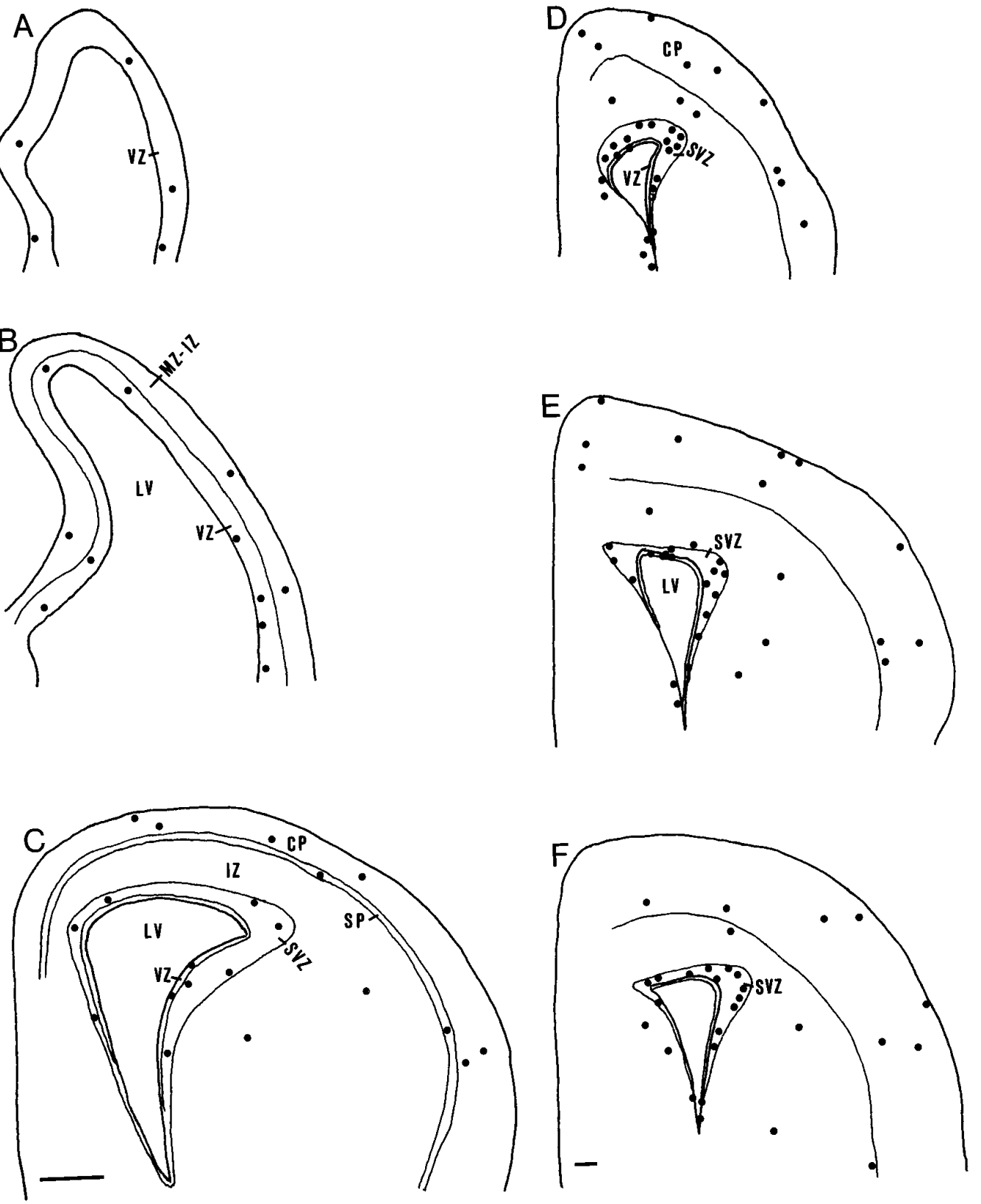

Figure 2. Camera lucida drawings of coronal sections through E14 $(A), \mathrm{E} 16(B), \mathrm{E} 19(C), \mathrm{P} 0(D), \mathrm{P} 7(E)$, and $\mathrm{P} 14(F)$ rat brains, illustrating the positions of dying cells, as revealed by TUNEL immunohistochemistry in $10-\mu \mathrm{m}$-thick paraffin sections. $C P$, Cortical plate; $I Z$, intermediate zone; $L V$, lateral ventricle; $M Z$, marginal zone; $S P$, subplate; $S V Z$, subventricular zone; $V Z$, ventricular zone. Calibration bars: $A-C$ and $D-F, 200 \mu \mathrm{m}$.

to be less sensitive than the histochemical visualization of TUNEL-positive cells (Gavrieli et al., 1992). A hallmark of apoptosis is the degradation of DNA into oligonucleosomal-sized fragments, displayed in gel electrophoresis as a DNA "ladder" (Wyllie, 1980). We performed DNA extraction from the SVZ of newborn rats as well as from adult cerebral cortex. After electrophoretical separation of the different DNA samples, the SVZ showed DNA fragmentation, which appeared as a smear (Fig. 8, lane 3). The cerebral cortex of adult rats, processed in the same way and used as a negative control because of the low number of TUNEL-positive cells (data not shown), gave a distinct DNA band without any signs of fragmentation (Fig. 8, lane 4). As a positive control of DNA "laddering" (Fig. 8, lane 2), we used cultured thymocytes treated with dexamethasone, which is known to cause apoptotic cell death (Wyllie, 1980; Cohen and Duke, 1984; Walker et al., 1991).

\section{DISCUSSION}

We have used here a combination of TUNEL histochemistry and S-phase markers to investigate the link between cell division and programmed cell death in the proliferative layers of the developing cerebral cortex. The largest number of dying cells was found in the SVZ of newborn rats, where one in every two newly generated cells dies. We found that $57 \%$ of SVZ cells are proliferating at birth with a cell cycle time of $18 \mathrm{hr}$ and that most of the TUNEL-labeled cells belong to the proliferative population. Using two S-phase markers in succession to provide a cohort of identifiable cells that proceed together along the cell cycle, we found that TUNEL-positive cells 


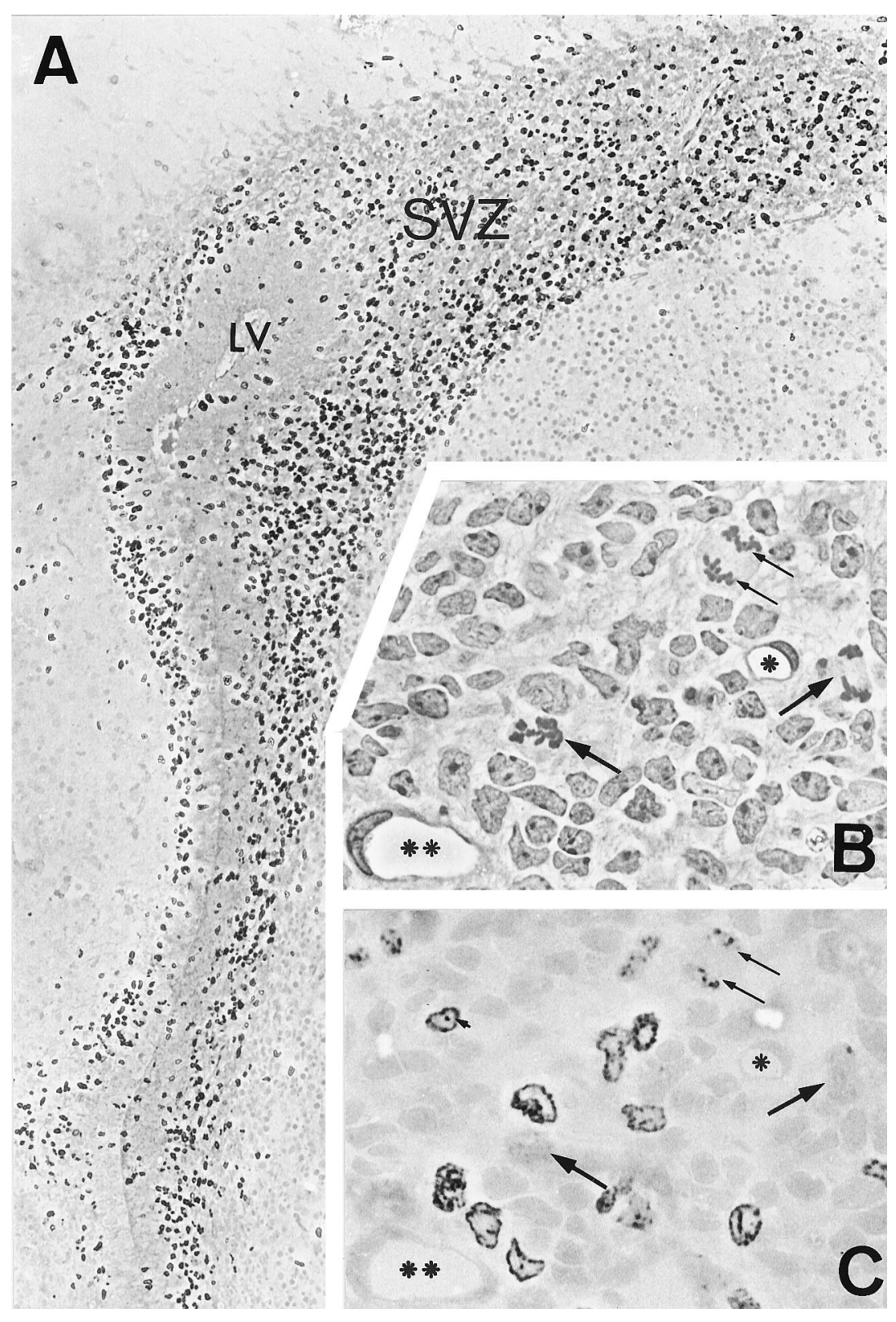

Figure 3. Illustrations of the methods used for the evaluation of the length of the cell cycle in the SVZ of newborn rats. $A$, Cumulative BrdU labeling indicating the maximum number of dividing cells after multiple BrdU injections. $L V$, Lateral ventricle. $B$, Toluidine blue staining of a semithin section through the SVZ, where mitotic figures are indicated by arrows. $C$, Adjacent section to the previous one, stained with anti-BrdU monoclonal antibody, showing labeled (thin double arrows) and unlabeled mitoses (thick arrows). Asterisks mark the same blood vessels in consecutive sections. Magnification: $A, 110 \times ; B, C, 640 \times$. could be visualized for $\sim 2 \mathrm{hr}$ and that $79 \%$ of the deaths of proliferating SVZ cells occur during the first part of G1.

\section{Sensitivity of histological techniques to detect apoptosis and clearance time}

The ability to visualize dying cells using histological techniques is related strictly to the time during which dead cells are detectable before they are cleared away by phagocytosis. This clearance time may be different to the length of the whole process, which lasts from the time a cell is committed irreversibly to die to its final removal, and depends on the sensitivity of the method used to visualize dying cells. Clearance time may be used to calculate the total number of cells dying in a tissue over a given period. The most sensitive method reported to date for detecting dying cells is ISEL (Blaschke et al., 1996), a modification of the TUNEL method (Gavrieli et al., 1992), applied in unfixed, frozen sections. A similar treatment of the tissue, using T7 DNA polymerase instead of TdT, was used by Wood et al. (1993) to detect dying cells in the developing cerebellum. The large numbers of dying or dead cells visualized with these techniques can be justified only with a long clearance time, as suggested by Voyvodic (1996): "... the clearance time must be considerably longer than the cell cycle time or there would be no net increase in cell number." However, with a clearance time longer than the cell cycle, ISELpositive cells should accumulate in the proliferative zone so that more of these cells would be present at E16 than at E14, unlike the results of Blaschke et al. (1996). Although the rate of removal of dead cells may vary in different tissues, previous evaluations in other areas of the developing nervous system suggest this occurs rapidly (Barres et al., 1992; Voyvodic et al., 1995).

Most of the histological methods used to detect apoptotic cells are based on the morphological changes occurring at the level of the cell nucleus. Although nuclear staining with propidium iodide or toluidine blue reveals clumps of chromatin or nuclear condensation, which are marks of advanced nuclear damage, the TUNEL method may detect DNA breaks before morphological changes are apparent (Gavrieli et al., 1992). The relatively low number of 
A

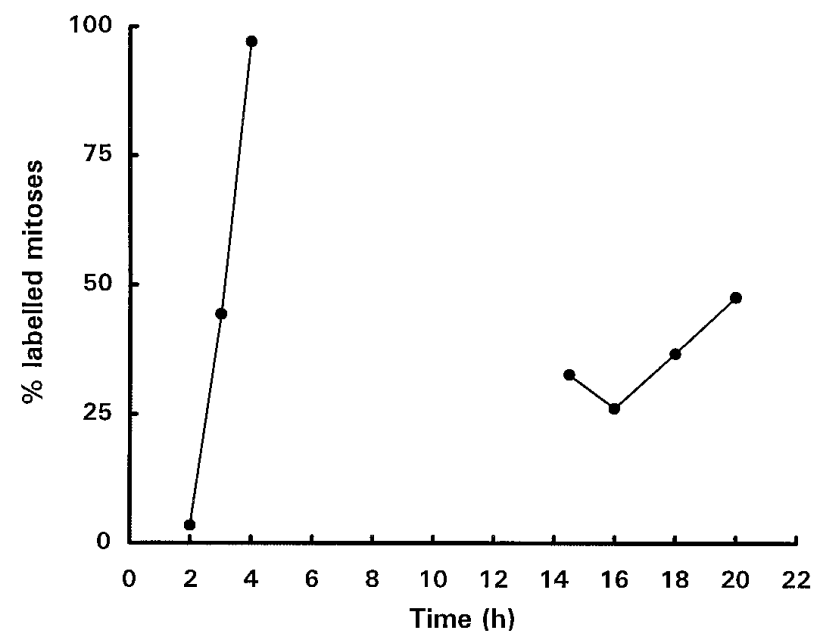

B

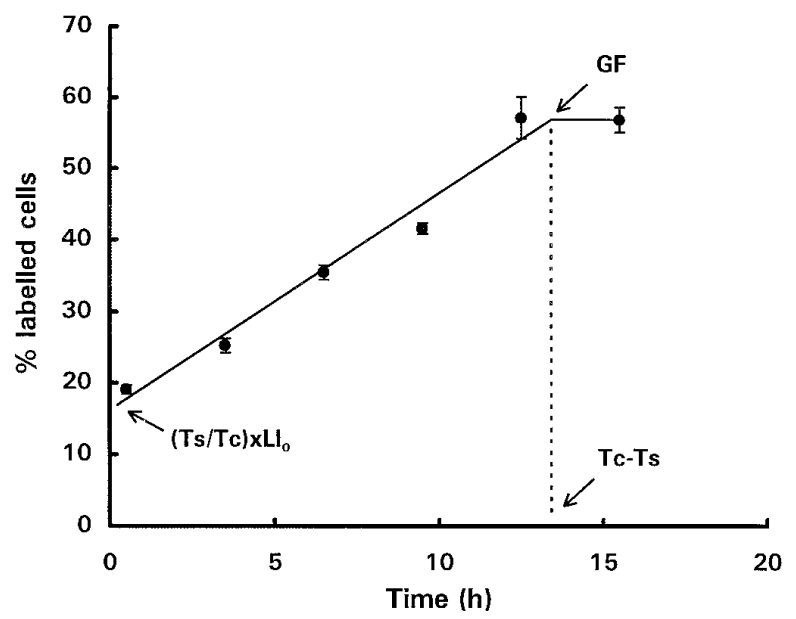

Figure 4. A, The percentage of labeled mitoses method was used to determine the length of $T_{\mathrm{C}}$ and $T_{\mathrm{G} 2+\mathrm{M}}$ of newborn SVZ cells. The results shown arise from two separate sets of experiments, one in paraffin sections and the other in semithin Araldite sections. After a pulse of BrdU at time 0 , labeled mitoses were seen first after $2 \mathrm{hr}$, and the number increased rapidly to $100 \%$. From this initial slope, the length of $\mathrm{G} 2+\mathrm{M}$ can be estimated as the interval between the injection and the time when labeling reached $50 \%$, i.e., $3 \mathrm{hr}$. The number of labeled mitoses increased again as daughters of the initially labeled cells began the second round of division. The interval between the $50 \%$ points of the two successive ascending curves represents the length of $T_{\mathrm{C}}$ and corresponds to $\sim 17 \mathrm{hr}$. $B$, Cumulative BrdU labeling of newborn SVZ cells. Each data point represents the mean \pm SEM of counts obtained from five different animals. From an extrapolation of a linear repression line drawn through the initial ascending curve, the percentage of cells labeled at time $0\left(\mathrm{LI}_{0}\right)$ was $15.7 \%$, and the time taken to reach the plateau was $13.5 \mathrm{hr}\left(T_{\mathrm{C}}-T_{\mathrm{S}}\right)$. From these data, $T_{\mathrm{C}}$ was calculated as $18.6 \mathrm{hr}$ and $T_{\mathrm{S}}$ as $5.1 \mathrm{hr}$.

TUNEL-positive cells found in this study and in previous reports (Herrup and Busser, 1995; Spreafico et al., 1995; Valverde et al., 1995) suggests that these cells are cleared away quickly by phagocytosis. In the present study, we have estimated that TUNELlabeled cells in the SVZ of newborn rats are removed in $2-3 \mathrm{hr}$. This clearance time is within the range of previous reports that used different approaches, including direct observation in cultures (for review, see Bursch et al., 1990; Barres et al., 1992; Voyvodic $\nabla$

A

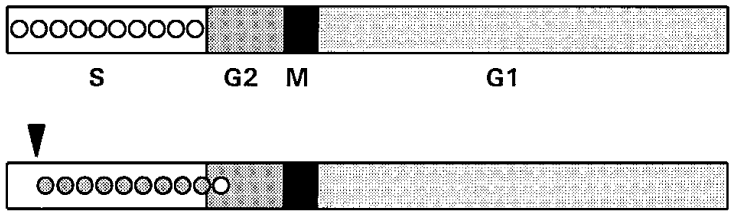

C

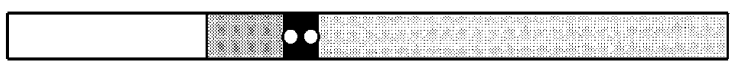

D

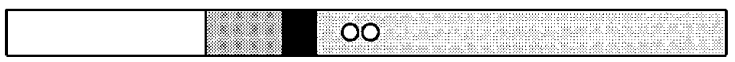

E

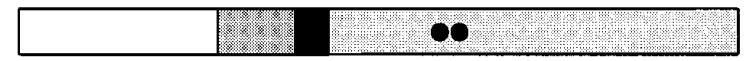

$\mathbf{F}$

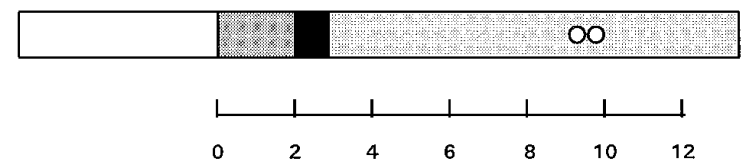

Figure 5. Schematic representation of the experimental procedure used to mark a cohort of dividing cells and trace them throughout the cell cycle. Open circles, BrdU-labeled cells; gray circles, BrdU and $\left[{ }^{3} \mathrm{H}\right]$-thymidinelabeled cells; black circles, BrdU and TUNEL-positive cells. A, Rats received a single injection of $\mathrm{BrdU}$ at 0 min (open arrow) that marked all cells passing through $\mathrm{S}$ phase at that time. $B$, After $40 \mathrm{~min}$, rats received an injection of $\left[{ }^{3} \mathrm{H}\right]$-thymidine (black arrow), which also labeled cells passing through $\mathrm{S}$ phase. Only a cohort of cells that had exited the S phase during the last $40 \mathrm{~min}$ and were BrdU-positive, but $\left[{ }^{3} \mathrm{H}\right]$-thymidinenegative (open circles), was followed. $C$, At $2 \mathrm{hr}$ after the first injection, these cells were in mitosis and showed no sign of apoptosis, as indicated using TUNEL immunohistochemistry. $D$, At $4 \mathrm{hr}$ after the first injection, these cells were in early $\mathrm{G} 1$ and again showed no sign of apoptosis. $E$, BrdU-positive- $\left[{ }^{3} \mathrm{H}\right]$-thymidine-negative cells died during a narrow time window 5-8 hr after the injection of BrdU and were not seen to die at a later time within $\mathrm{G} 1(F)$.

et al., 1995). The results obtained with the TUNEL method are in agreement with electron microscopical observations of the developing cortex (Shoukimas and Hinds, 1978; present study).

\section{Cell death in proliferating nervous tissue}

The occurrence of dying cells in the proliferative zones of the brain (Morshead and van der Kooy, 1992; Acklin and van der Kooy, 1993; Wood et al., 1993; Herrup and Busser, 1995; Reznikov and van der Kooy, 1995; Blaschke et al., 1996) suggests that cell death is not an exclusive feature of postmitotic cells competing for trophic factors (Oppenheim, 1991). Cell death in proliferating tissue may be facilitated by the presence of an active cell cycle machine; indeed, many regulators of the cell cycle are involved in the pathways that lead to apoptosis (Ross, 1996). A primary function in linking cell cycle and cell death is exerted by proteins acting as cell cycle checkpoints. One of them, E2F-1, is a key regulator of the $\mathrm{G} 1$ to $\mathrm{S}$ transition (Weinberg, 1992). In mice lacking E2F-1 via homologous recombination, normal apoptosis is suppressed (Fields et al., 1996). Other transcriptional regulators of the G1 to S checkpoint (e.g., p53) also are involved in promoting apoptosis (Symonds et al., 1994). The use of the same machinery in 


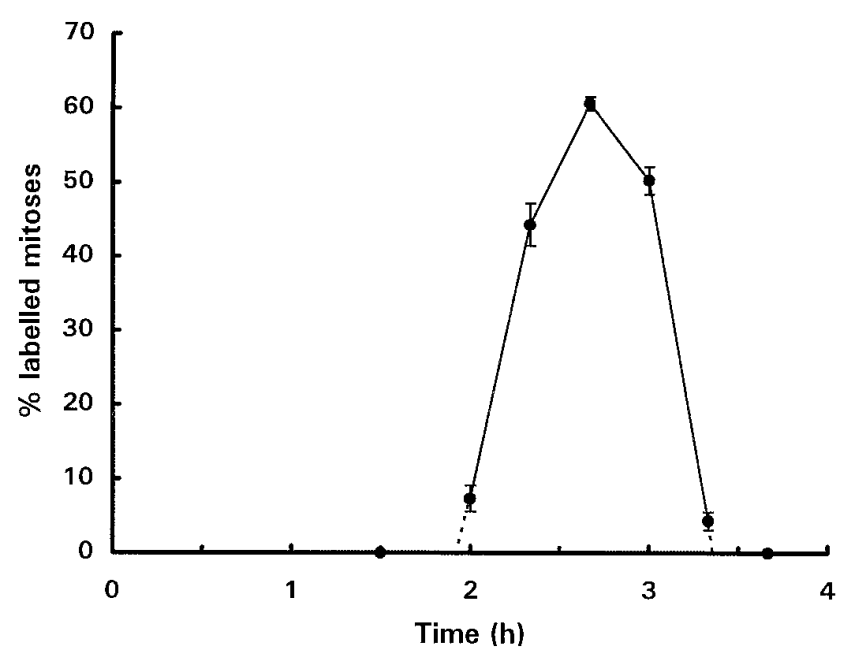

Figure 6. The percentage of labeled mitoses method also was used to evaluate the length of $M$ phase for cycling newborn SVZ cells. An identifiable cohort of cells moving synchronously along the cell cycle entered $\mathrm{G} 1$ phase $1 \mathrm{hr}$ and $50 \mathrm{~min}$ after the injection of the first S-phase marker. Mitoses labeled only with this marker were visible for a total of 1.5 hr. After subtracting the length between injections of the two S-phase markers, the length of $\mathrm{M}$ phase was estimated to be no more than $50 \mathrm{~min}$. Each point represents the mean \pm SEM of counts in three different animals.

the opposing processes of cell death and cell cycle progression may be instrumental in eliminating cells carrying mutations, which may be produced in large numbers by proliferating tissue, or it may be an indication that one of the two processes (i.e., cell death) is necessary for the other (e.g., via the release of basic fibroblast growth factor from dying cells, which in turn stimulates proliferation) or for the histogenesis of the mature organ or tissue that is being generated (Caviness et al., 1995). Support for the existence of a molecular link between cell death and cell division comes from a number of studies describing the activation of the cell cycle machinery in postmitotic neurons undergoing cell death (al-Ubaidi et al., 1992; Lee et al., 1992; Yonish-Rouach et al., 1993; Freeman et al., 1994). Herrup and Busser (1995) endorsed the hypothesis that cell death in postmitotic neurons is a consequence of unscheduled cell division and stressed its occurrence in various forms of target-related cell death.

\section{Apoptosis takes place during $\mathrm{G1}$}

Several studies have reported labeling of dying cells with S-phase markers (Herrup and Busser, 1995; Reznikov and van der Kooy, 1995). However, this finding is not conclusive proof of proliferative activity, because uptake may have occurred passively in cells with severely damaged DNA. There are at least two lines of evidence to indicate that cells dying in the proliferative zones of the brain were passing through $\mathrm{S}$ phase immediately before apoptosis. First, after cumulative labeling with BrdU, we found a significant number $(21 \%)$ of TUNEL-positive cells that were not labeled with this S-phase marker. This indicates that the labeling of TUNEL-positive cells with BrdU is not a result of nonspecific uptake of this marker and suggests that the unlabeled cells dying in the SVZ may have been postmitotic. In fact, in our protocol, the exposure to BrdU was longer than $T_{\mathrm{C}}-T_{\mathrm{S}}$, ensuring that all cycling cells were passing through $\mathrm{S}$ phase while BrdU was available (Nowakowski et al., 1989). The second line of evidence comes from a study performed on dying cerebellar granule neurons in staggerer and lurcher mutants (Herrup and Busser, 1995). This study showed that, in addition to the uptake of BrdU, dying
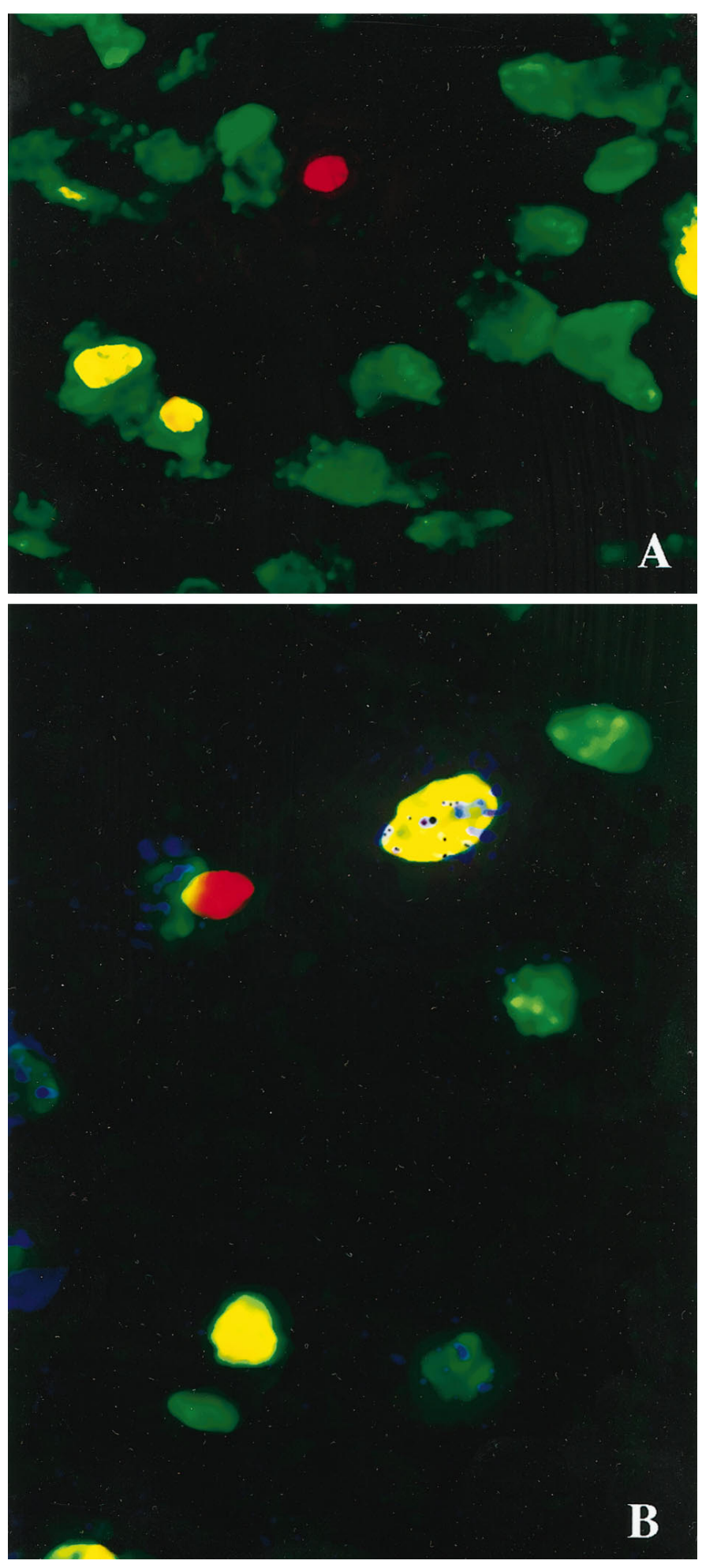

Figure 7. A, Confocal image showing colocalization (yellow) of TUNEL-positive cells (red) with BrdU (green) after $15.5 \mathrm{hr}$ of BrdU cumulative labeling. Note that not all TUNEL-positive cells are dividing. $B$, Confocal image showing a number of labeled SVZ cells: BrdUlabeled (green), TUNEL-positive (red), double-labeled (BrdUTUNEL, yellow; $\operatorname{BrdU}-\left[{ }^{3} \mathrm{H}\right]$ thymidine, green with blue grains), and triple-labeled cells (TUNEL-BrdU- $\left[{ }^{3} \mathrm{H}\right]$-thymidine, yellow with blue grains). Magnification, $560 \times$. 


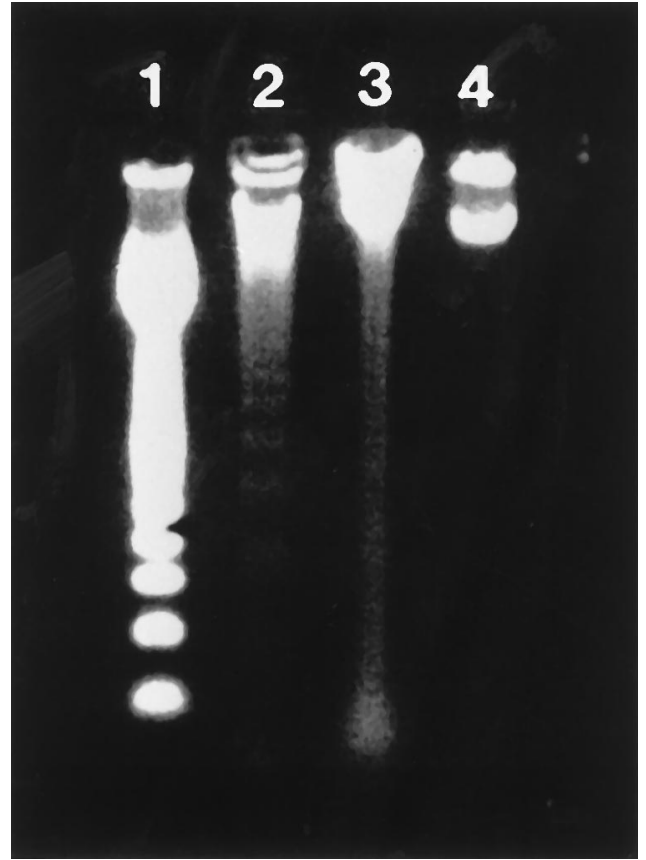

Figure 8. Agarose gel showing DNA fragmentation in the SVZ. Lane 1, 100 bp DNA ladder; lane 2, DNA from cultured thymocytes treated with dexamethasone; lane 3, DNA extracted from the SVZ of newborn rats showing a characteristic pattern of DNA fragmentation; lane 4, DNA extracted from adult cerebral cortex, used as a negative control of apoptosis.

cells express other markers of proliferation, namely proliferating cell nuclear antigen and cyclin $\mathrm{D}$. These data suggest that the commitment to die and the execution of this program follow the replication of DNA that takes place in $\mathrm{S}$ phase. It is unclear whether dying cells in the proliferative regions are tetraploid, which would indicate that death occurred before the completion of mitosis. In a recent study, Yaginuma et al. (1996) found extensive cell death in the spinal cord of chick embryos, where motoneurons died shortly after exiting the cell cycle. These cells had taken up $\left[{ }^{3} \mathrm{H}\right]$-thymidine $12 \mathrm{hr}$ or longer before dying and already had expressed markers of differentiation, suggesting that they had passed through mitosis and were in G1 or G0 phases at the time of death. In accordance with the hypothesis that death occurs after mitosis, it has been reported that $50 \%$ of the newly generated oligodendrocytes of the rat optic nerve die shortly after becoming postmitotic (Barres et al., 1992). Other indirect evidence that cell death in the nervous system occurs after mitosis was provided by the study of Morshead and van der Kooy (1992), in which the size of the subependymal clones labeled with a recombinant retrovirus did not increase with time. The authors attributed the lack of increase in clonal size to the death of one of the two daughters, which regularly occurred after mitosis. One interpretation of these findings is that both DNA synthesis and mitosis occur in an orderly manner in dying cells, but commitment to die takes place in early G1. The timing of the appearance and disappearance of TUNEL-positive cells in the SVZ after a double pulse of S-phase markers, which is similar to that reported by others (Herrup and Busser, 1995; Reznikov and van der Kooy, 1995), is consistent with the onset of cell death soon after mitosis.

\section{Extent of cell death in the developing telencephalon}

To obtain a true estimate of the extent of cell death in proliferating tissue, we believe it is necessary to know parameters of the cycling population that include the size of the founder population, the length and number of cell cycles in the interval to be studied, the production of dividing and postmitotic cells, and whether these cells remain in the proliferative areas or migrate away. Many of these parameters are known for the E14-E18 mouse telencephalon that has been studied extensively by Takahashi and colleagues (Takahashi et al., 1992, 1993, 1994, 1995a,b). However, a good estimate of the number of dying cells as related to the number of cells born at each cell division can be obtained by comparing the number of cells in a particular phase of the cell cycle (i.e., cells in mitosis) and that of dying cells (as detected with TUNEL histochemistry, for example), given that the lengths of the two processes are known and are shorter than the cell cycle itself. We have evaluated these parameters for the proliferative population of the newborn rat SVZ, which showed the highest number of TUNEL-positive cells, and found that TUNEL-labeled nuclei can be visualized for a duration approximately three times longer than the length of mitosis. This means that, if at a given time one mitosis and one dying cell are present in tissue, it actually represents one cell dying for every three mitoses.

Computation of the number of newly generated VZ cells that die before becoming part of the postmitotic population indicates that $\sim 1.7 \%$ of the cells generated by dividing progenitors at E14, $8.8 \%$ of those generated at E16, $17.5 \%$ of E19, and $\sim 37 \%$ of those generated by dividing SVZ cells at birth die. The occurrence of this large extent of cell death in the proliferative layers of the developing cortex is not surprising and was predicted by lineage studies in which recombinant retroviruses were used in combination with birthdate markers (Acklin and van der Kooy, 1993) (M. C. Mione, unpublished data) and by computational models of cortical development (Caviness et al., 1995). However, it should be kept in mind that this is not the only wave of cell death that affects the developing cerebral cortex. A comparable or even greater loss of neurons takes place during postnatal development. Miller (1995) estimated that as many as $50 \%$ of the interneurons of the cortex and $20 \%$ of the projection neurons undergo cell death between P6 and P60. These losses may correspond to the massive cell death occurring before the third postnatal week in rats, as described by other authors using conventional histological techniques (Finlay and Slattery, 1983; Ferrer et., 1992). It is unclear whether these late deaths are preceded by activation of cell cycle genes and whether they involve DNA fragmentation detectable with TUNEL histochemistry. Our results indicate that cell death is an important event in the development of the cerebral cortex, acting as a regulatory mechanism to control cell numbers during corticogenesis.

\section{REFERENCES}

Acklin SE, van der Kooy D (1993) Clonal heterogeneity in the germinal zone of the developing rat telencephalon. Development (Camb) 118:175-192.

al-Ubaidi MR, Hollyfield JG, Overbeek PA, Baehr W (1992) Photoreceptor degeneration induced by the expression of simian virus 40 large tumor antigen in the retina of transgenic mice. Proc Natl Acad Sci USA 89:1194-1198.

Barres BA, Hart IK, Coles HSR, Burne JF, Voyvodic JT, Richardson WD, Raff MC (1992) Cell death and control of cell survival in the oligodendrocyte lineage. Cell 70:31-46.

Baserga R (1985) The biology of cell reproduction. Cambridge, MA: Harvard UP.

Blaschke AJ, Staley K, Chun J (1996) Widespread programmed cell death in proliferative and postmitotic regions of the fetal cerebral cortex. Development (Camb) 122:1165-1174.

Bursch W, Kleine L, Tenniswood M (1990) The biochemistry of cell death by apoptosis. Biochem Cell Biol 68:1071-1074. 
Caviness Jr VS, Takahashi T, Nowakowski RS (1995) Numbers, time, and neocortical neurogenesis: a general developmental and evolutionary model. Trends Neurosci 18:379-383.

Clarke PGH (1990) Developmental cell death: morphological diversity and multiple mechanisms. Anat Embryol (Berl) 181:195-213.

Cohen JJ, Duke RC (1984) Glucocorticoid activation of a calciumdependent endonuclease in thymocyte nuclei leads to cell death. J Immunol 132:38-42.

Ferrer I, Soriano E, Del Rio JA, Alcantara S, Auladell C (1992) Cell death and removal in the cerebral cortex during development. Prog Neurobiol 39:1-43.

Fields SH, Tsai F-Y, Kuo F, Zubiaga AM, Kaelin Jr WG, Livingstone DM, Orkin SH, Greenberg ME (1996) E2F-1 functions in mice to promote apoptosis and suppress proliferation. Cell 85:549-561.

Finlay BL, Slattery M (1983) Local differences in the amount of early cell death in neocortex predict adult local specializations. Science 219:1349-1351.

Freeman RS, Estus S, Johnson Jr EM (1994) Analysis of cell cyclerelated gene expression in postmitotic neurons: selective induction of cyclin D1 during programmed cell death. Neuron 12:343-355.

Gavrieli Y, Sherman Y, Ben-Sasson SA (1992) Identification of programmed cell death in situ via specific labeling of nuclear DNA fragmentation. J Cell Biol 119:493-501.

Geelen JA, Langman J (1977) Closure of the neural tube in the cephalic region of the mouse embryo. Anat Rec 189:625-640.

Glücksmann A (1951) Cell death in normal vertebrate ontogeny. Biol Rev 26:59-86.

Graham A, Heyman I, Lumsden A (1993) Even-numbered rhombomeres control the apoptotic elimination of neural crest cells from oddnumbered rhombomeres in the chick hindbrain. Development (Camb) 119:233-245.

Herrup K, Busser JC (1995) The induction of multiple cell cycle events precedes target-related neuronal death. Development (Camb) 121:2385-2395.

Herrup K (1983) Role of staggerer gene in determining cell number in the cerebellar cortex. I. Granule cell death is an indirect consequence of staggerer gene action. Dev Brain Res 11:267-274.

Homma S, Yaginuma H, Oppenheim RW (1994) Programmed cell death during the earliest stages of spinal cord development in the chick embryo: a possible means of early phenotypic selection. J Comp Neurol 345:377-395.

Ignacio MPD, Kimm EJ, Kageyama GH, Yu J, Robertson RT (1995) Postnatal migration of neurons and formation of laminae in rat cerebral cortex. Anat Embryol (Berl) 191:89-100.

Kuerbitz SJ, Plunkett BS, Walsh WV, Kastan MB (1992) Wild-type p53 is a cell cycle checkpoint determinant following irradiation. Proc Natl Acad Sci USA 89:7491-7495.

Lee EH, Chang CY, Hu N, Wang YC, Lai CC, Herrup K, Lee WH, Bradley A (1992) Mice deficient for Rb are nonviable and show defects in neurogenesis and haematopoiesis. Nature 359:288-294.

Martín-Partido G, Alvarez IS, Rodriguez-Gallardo L, Navascues J (1986) Differential staining of dead and dying cells with a simple new technique. J Microsc 142:101-106.

Meikrantz W, Gisselbrecht S, Tam SW, Schlegel R (1994) Activation of cyclin A-dependent protein kinases during apoptosis. Proc Natl Acad Sci USA 91:3754-3758.

Miller MW (1995) Relationship of the time of origin and death of neurons in rat somatosensory cortex: barrel versus septal cortex and projection versus local circuit neurons. J Comp Neurol 355:6-14.

Mione MC, Danevic C, Boardman P, Harris B, Parnavelas JG (1994) Lineage analysis reveals neurotransmitter (GABA or glutamate) but not calcium-binding protein homogeneity in clonally related cortical neurons. J Neurosci 14:107-123.

Morshead CM, van der Kooy D (1992) Postmitotic death is the fate of constitutively proliferating cells in the subependymal layer of the adult mouse brain. J Neurosci 12:249-256.

Nowakowski RS, Lewin SB, Miller MW (1989) Bromodeoxyuridine immunohistochemical determination of the lengths of the cell cycle and the DNA-synthetic phase for an anatomically defined population. J Neurocytol 18:311-318.

Oppenheim RW (1991) Cell death during development of the nervous system. Annu Rev Neurosci 14:453-501.

Pardee AB (1989) G1 events and regulation of cell proliferation. Science 246:603-608.
Parnavelas JG, Luder R, Pollard CG, Sullivan K, Lieberman AR (1983) A qualitative and quantitative ultrastructural study of glial cells in the developing visual cortex of the rat. Philos Trans R Soc Lond [Biol] 301:55-84.

Raff MC, Barres BA, Burne JF, Coles HS, Ishizaki Y, Jacobsen MD (1993) Programmed cell death and the control of cell survival: lessons from the nervous system. Science 262:695-700.

Reznikov K, van der Kooy D (1995) Variability and partial synchrony of the cell cycle in the germinal zone of the early embryonic cerebral cortex. J Comp Neurol 360:536-554.

Ross EM (1996) Cell division in the nervous system: regulating the cycle from neuronal differentiation to death. Trends Neurosci 19:62-68.

Saunders Jr JW (1966) Death in embryonic systems. Science 154:609-612.

Schultze B, Nowak B, Maurer W (1974) Cycle times in the neural epithelial cells of various types of neurons in the rat. An autoradiographic study. J Comp Neurol 158:207-218.

Shoukimas GM, Hinds JW (1978) The embryonic development of the cerebral cortex in the mouse: an electron microscopical serial section analysis. J Comp Neurol 179:795-830.

Spreafico R, Frassoni C, Arcelli P, Selvaggio M, De Biasi S (1995) In situ labeling of apoptotic cell death in the cerebral cortex and thalamus of rats during development. J Comp Neurol 363:281-295.

Symonds H, Krall L, Remington L, Saenz-Robles M, Lowe S, Jacks T, Van Dyke T (1994) p53-Dependent apoptosis suppresses tumor growth and progression in vivo. Cell 78:703-711.

Takahashi T, Nowakowski RS, Caviness Jr VS (1992) BrdU as an S-phase marker for quantitative studies of cytokinetic behaviour in the murine cerebral ventricular zone. J Neurocytol 21:185-197.

Takahashi T, Nowakowski RS, Caviness Jr VS (1993) Cell cycle parameters and patterns of nuclear movement in the neocortical proliferative zone of the fetal mouse. J Neurosci 13:820-833.

Takahashi T, Nowakowski RS, Caviness Jr VS (1994) Mode of cell proliferation in the developing mouse neocortex. Proc Natl Acad Sci USA 91:375-379.

Takahashi T, Nowakowski RS, Caviness Jr VS (1995a) Early ontogeny of the secondary proliferative population of the embryonic murine cerebral wall. J Neurosci 15:6058-6068.

Takahashi T, Nowakowski RS, Caviness Jr VS (1995b) The cell cycle of the pseudostratified ventricular epithelium of the embryonic murine cerebral wall. J Neurosci 15:6046-6057.

Valverde F, Lopez-Mascaraque L, Santacana M, De Carlos JA (1995) Persistence of early-generated neurons in the rodent subplate: assessment of cell death in neocortex during the early postnatal period. J Neurosci 15:5014-5024.

Voyvodic JT, Burne JF, Raff MC (1995) Identification of normal cell death in the rat retina: applications for normal composition in cell lineage analysis. Eur J Neurosci 7:2469-2478.

Voyvodic JT (1996) Cell death in cortical development. How much? Why? So what? Neuron 16:693-696.

Waechter V, Jaensch B (1972) Generation times of the matrix cells during embryonic brain development: an autoradiographic study in rats. Brain Res 46:235-250.

Walker PR, Smith C, Yoodale T, Leblanc J, Whitfield TF, Sikorska M (1991) Topoisomerase II-reactive chemotherapeutic drugs induce apoptosis in thymocytes. Cancer Res 51:1078-1085.

Weinberg R (1992) The retinoblastoma gene and gene product. Cancer Surv 12:43-57.

Wetts R, Herrup K (1982) Interaction of granule, Purkinje, and inferior olivary neurons in lurcher chimeric mice. II. Granule cell death. Brain Res 250:358-362.

Wood KA, Dipasquale B, Youle RJ (1993) In situ labeling of granule cells for apoptosis-associated DNA fragmentation reveals different mechanisms of cell loss in developing cerebellum. Neuron 11:621-632.

Wyllie AH (1980) Glucocorticoid-induced thymocytes apoptosis is associated with endogenous endonuclease activation. Nature 284:555-556.

Wyllie AH, Kerr JFR, Currie AR (1980) Cell death: the significance of apoptosis. Int Rev Cytol 68:251-306.

Yaginuma H, Tomita M, Takashita N, McKay SE, Cardwell C, Yin Q-W, Oppenheim RW (1996) A novel type of programmed neuronal death in the cervical spinal cord of the chick embryo. J Neurosci 16:3685-3703.

Yonish-Rouach E, Grunwald D, Wilder S, Kimchi A, May E, Lawrence JJ, May P, Oren M (1993) p53-Mediated cell death: relationship to cell cycle control. Mol Cell Biol 13:1415-1423. 